\title{
BANK LENDING AND ENTREPRENEURSHIP DEVELOPMENT IN NIGERIA'S AGRICULTURAL AND MANUFACTURING SECTORS
}

\author{
Sotonye, George \\ University of Port Harcourt, Rivers State. \\ Tel: +2348033102089 \\ E-mail: George_sotonye@yahoo.com
}

Nwanyanwu, H. Dennis, Ph. D

Kenule Beeson Saro-Wiwa Polytechnic Bori, Rivers State.

\begin{abstract}
:
Banks and other financial institutions play important roles in building and sustaining agricultural and manufacturing sectors by assisting entrepreneurs in capital formations. This work examined the impact of bank loans on entrepreneurship development in Nigeria. Secondary data were sourced from CBN and SMEDAN the Annual Statistical Bulletin of various years 1981-2018. The Autoregressive Distributive Lag (ARDL) model which is an extension of OLS was adopted in the analysis. Results revealed that banks' loans to the agricultural sector has negative short run effect on entrepreneurship development in Nigeria but positive short run effect to the manufacturing sector. Further findings showed significant joint effect of bank lending to the agriculture and manufacturing sectors in enhancing entrepreneurship development in both sectors. The paper suggested for increase in loans to the agricultural sector by providing incentives that will attract farmers. Incentives such as lower interest rates, fertilizer subsidization and free extension services should be considered. The manufacturing sector should not be left out in the scheme of banks' lendings as they have shown to benefit more from these loans and have also increased in terms of more entrepreneurs springing up over the years and there should be a national data base of registered farmers and their loans history to facilitate loans to the agricultural sector.
\end{abstract}

Keywords: Bank Lending, Loan, Entrepreneurship Development 


\section{Introduction}

Building an entrepreneurship venture in both agriculture the manufacturing sector, the entrepreneur needs to access diverse forms of resources such as financial capital, human capital and physical capital with each playing significant. To a large extent, extractive activities have always provided the enabling resources for major secondary entrepreneurial activities but the bottom line remains their financing. No economic activity works without finance as no one can give what he/she does not have. It is only finance that any perceived business investment, be it extractive (primary) or manufacturing (secondary) entrepreneurship can be actualized. Besides intellectual development on any skill, competencies are proven through the deliverables of an individual evidenced in an industry. If this is through, then, the financing entrepreneurship business is essential. Financial adequacy and stability plays better roles in entrepreneurship development and the nation's economy at large. Entrepreneurship businesses may be relatively small or medium in size and may also be operating on a small or medium scale. Entrepreneurship business is pivotal for nations' economic growth (Ikpor, Nnabu \& Obaji, 2017). Naturally, entrepreneurship businesses were a cutting-edge to boost a nation's economy through the assistance of banks by avail them affordable loan facilities with a low interest rate (Sanusi, 2011). Conversely, the links between these sources and their effects on entrepreneurship are enormous. In Nigerian milieu, the crucial source of finding for entrepreneurship development is ostensibly not operational.

Thus, apart from the traditional banks, who perform finance related functions such as accepting money for saving, giving out loans, managing investments, giving financial investment advice etc. Banks and other financial institutions in particular, are important to an entrepreneur, because he will have cause to deal with them for one reason or the other. For instance, he would like expanding his enterprise and for this he may need bank loans or he may need to invest in other areas in which case, he may need the services of a finance house or an investment house. Because of all these, the entrepreneur needs to know the ability of the bank to make his business grow.

Finance is considered a major to Nigeria's entrepreneurship development. Banks which remains the biggest source of finance to this sub-sector have often, shield away due to inherent risks and uncertainties. In Nigeria, the fragile economic environment, social insecurity, ethno-religious violence and near absence of the requisite social infrastructure, has rendered entrepreneurship development costly, ineffective and inefficient, hence credit facilities from Banks. To mitigate lack of entrepreneurship financing, governments at various levels (Local, State and Federal) have in different ways paid attention to improvement of entrepreneurships funding. Some governments formulated policies to empower the growth, development and financing of entrepreneurship business. Others focused on assisting entrepreneurships to grow through incentives, loans and socio-economic contributions. For instance CBN has established entrepreneurship Credit Guarantee Scheme (ECGS), for promoting credit access by entrepreneurs in Nigeria. The Federal Government also approved billion of naira recently for entrepreneurship sub sector development. At the state level, Bayelsa State Government in July, 2014 signed a N2Billion entrepreneurships development partnership agreement with Bank Of Industry, Mainstreet Bank and Bank of Agriculture. The overall objective of banks' participation in entrepreneurships financing is that, entrepreneurship remains a critical aspect for economic diversification, wealth and job opportunities, increased output and providing industrial sector 
inputs among others. An Entrepreneur needs his/her productivity increase through adequate financing if they are to maintain or increase their contribution to the economy in general.

In terms of manufacturing, neglect of the sector has eventually made the country monolithic unlike the historical experiences of Britain, US, Germany, Japan, Russia and of late, emerging economies from Asia, notably China, India, Singapore, Taiwan, Thailand South Korea, Malaysia Brazil and even of recent, Ghana (Obidigbo, 2012)

Supporting the same frame of thought, a study by the Federal Republic of Nigeria (2011) held that the low quality of bank funding to the private sector went down increasingly as the risk aversion of banks increased after the financial meltdown. Lack of funding has made it difficult for firms to invest in modern machines, communication technology and human resources development which are essential factors in trimming down costs, raising productivity and improving competitive strength.

Nigeria's economy essentially rests on the economic especially agriculture and the manufacturing sectors. According to Taiwo and Omosomi, (2018), in a disaggregated analysis, Nigeria's agriculture contributed 32\% in Africa's GDP 2017 which was second to Ethiopia with $34 \%$ contribution. This explains the need for more attention on agricultural financing.

Again, in 2017, agriculture budget of N0.10 trillion represented 1.3\% of total budget of N7.44 trillion. According to Taiwo and Omosemi, (2018), in another disaggregated form, from 2013 to 2017, budgetary allocation to agriculture showed that in 2013, out of a total budget of N83.2b, N4.66b was allocated to agriculture, in 2014, agriculture had a share of N4.9b out of N66.6b budget. In 2015, N4.5b from a total of N40.6b was allocated to agriculture. And, in 2016, from a budget of N75.8bn, agriculture had N6.06bn while in 2017, N7.4b was allocated to agriculture from a total budget of N135.6n. And in 2018, allocation to agriculture was N0.20 trillion representing 2.2\% of the proposed 2018 budget of N9.12 trillion. In the midst of such existing gaps, the question raised is, how well have banks made financial credits available towards entrepreneurship development considering existing unemployment, untapped resources and entrepreneurship opportunities in Nigeria? Against this backdrop, the major problem of this work is to assess the extent to which bank loans to agriculture and the manufacturing sectors have contributed to Nigeria's gross domestic product (GDP) from 1981 to 2018.

The study broad objective is to examine the of impact bank loans on development of entrepreneurship in Nigeria. The specific objectives are to: (i) ascertain the level of relationship between bank loans distributed to agricultural sector and the contributions of agricultural sector to Nigeria's gross domestic product and (ii) evaluate the extent to which bank loans to the manufacturing sector have contributed to Nigeria's gross domestic product.

The study hypotheses are; $\mathrm{H}_{\mathrm{O} 1}$ : Significant relationship does not exist between bank loans to the agricultural sector and contribution of agricultural sector to Nigeria's gross domestic product. $\mathrm{H}_{\mathrm{O} 2}$ : Nigeria's manufacturing sector contributions to the gross domestic product has not significant relationship with the value of bank loans advanced to the manufacturing sector. The paper focuses on entrepreneurship development of entrepreneurship and banks' lending to Nigeria's Agricultural and manufacturing sectors in Nigeria from 1981 to 2018. The scope is 
organized in the following sections; the first section introduced the work, looking at the statement of problems, objectives and hypotheses. In the second section, words that helped to clarify the topic were explained. Theory behind the work was introduced while cursory discussions on studies done by other scholars in similar issues were discussed. The study methodology was introduced. Analysis and results discussed in the third section. The fourth section summarized the work, followed by conclusion and recommendations.

\section{Conceptual Issues}

Bank takes deposits and pays interest for their use, and then turns around and lends out the money to borrowers who typically pay for it at a higher interest rate. Thus, money is made available to customers by the banks at varying interest rates as cost of fund. Bank effectively acts as a financial intermediary between savers who deposit their money and investors who need the money (Yusuf, 2015). Accepting short-term deposits and issuing long-term loans by bank creates a mismatch (Emenuga, 2019). Profits can be measured as a return on assets and as a return on equity, which invariably shows the profit amounts obtained from the assets and expense of the liabilities. Lending is the act of borrowing out money for the single purposes of making profit. The ultimate aim to the lender may be interest chargeable while to the borrower, it profit. However, not every fund borrowed is utilized for investment. Reason for borrowing of fund varies. It could be spent on child's education/training, investment, marrying new wives and others. Hussain, Bhuiyan and Bakar (2014) conceived entrepreneurship as introduction of businesses with the sole aim of solving problems. It could be trading, manufacturing, agriculture and consultancy. The final purpose is that service is rendered and problems are solved. Given the perceptions of various scholars, entrepreneurship could be defined as a combination of performance of activities and learning of new skills of rendering services to assume the role of an entrepreneur.

\section{Entrepreneurship Sectors of the Economy}

For efficient allocation of resources, the every economy is divided into sectors. These sectors exist opportunities where conceived entrepreneurship ideas can be developed to create goods and services. To this end, Aremu \& Adeyemi, (2011) identified the sectors not limited to; (a) Agriculture, Hunting, Forestry and Fishing, (b) Mining and Quarrying, (c) Manufacturing, (d) Building and Construction, (e) Retail and wholesale Trade (f) Hotels and Restaurants, (g) Transportation, Storage and Communications. Others include; (h) Real Estate, Renting services Activities, (i) Education, (j) Health and Social Work, (k) Community, Social and Personal Services and (1) formal and informal financial intermediation. The formal part which is large scale such as banks and other financial institutes. Whereas, the informal intermediaries operate involves co-operative group, esusu, local money lenders, black market foreign exchange, etc.

\section{Entrepreneurship Role in Economic Development}

Oduntan (2014) identified that Entrepreneurship Business plays a pivotal role in any economy. These roles are not limited to the following employment generation, industrial development, technological acquisition, capacity building and promotion of economic growth. Further roles of in the economy encompasses; increased standard of living, export promotion, alleviation of poverty, output services through backward and forward linkages and generation of mutual industries linkages between local producers of raw materials and large industries concerns. 


\section{Theoretical Consideration}

Theoretical consideration for this paper is the innovation theory of entrepreneurship propounded by Joseph Schumpeter (1934) which is a development economics theory. Schumpeter defined entrepreneurship as a creative activity. This theory conceives entrepreneurship as one who is innovative and a manager in resources combination. The term innovation from Schumpeter point of view, explains that an entrepreneur must be a great thinker who thinks toward service provision, goods production, resources management in a scarcity environment as income generating opportunities. An Entrepreneur produces new goods or products and services into the economy (Idemobi, 2010). Entrepreneurship innovations are propelled by good economic system and avers to moribund economy. It implies that business climate must be conducive for entrepreneurship activities to help grow the economy. Limiting factors such as squeezing of private gains through high taxation and uneven government price controls and taxation will ultimately discourage entrepreneurship. This theory is the basis for this study because, if microfinance banks are active and playing relevant roles in the development of entrepreneurship in Nigeria, young entrepreneurs will increase their insight and knowledge to act where opportunities to provide services may arise.

\section{Empirical Studies}

Several studies have related bank lending to entrepreneurship development: (Adeleke \& Elumah, 2018: Muogbo \& Tomola, 2018: Nelson \& Ayawei, 2018). Buttressing this fact came the work of Jain, (2015) on Empirical Study of Development Banks and Entrepreneurship Promotion using descriptive statistics and content analysis, revealed that environmental factors, financial constraints and government policies were some of the militating factors against entrepreneurship promotion in India. The paper suggested for government to adopt a better approach in ensuring that banks offer loans to intending and existing entrepreneurs at a lower and unified interest rate. Similar in India "Entrepreneurship development through banks funding by Sushmitha \& Swathi, (2018) using product moment correlation coefficient, it was discovered that financial institutions increased as they should meet the need of financial assistance to new startup company as it was focused on roles banks play in facilitating economic growth through creation of financial credits to entrepreneurs. Encouragement of banking activities to sustain their assistance to entrepreneurs was suggested in the paper.

A work on "financial and manufacturing sector" was done by Ogunsakin, (2014). Multi-variant method was employed on time series data. The work revealed that reforms in the financial sector did impact significantly on out-put of the manufacturing sector growth in Nigeria during study period. On "manufacturing credit financing in Nigeria" studied by Kalu, et al, (2017) using OLS regression, found overwhelmingly that it takes about three years to restore the long-run equilibrium state on manufacturing sector output. Study suggested for CBN's and other monetary authorities alike should make policy that will lead to increase in volume of banks' credit.

In studying banks' lending, and manufacturing sector performance in Nigeria, Tomola, et al, (2018), adopted cointegration and vector error correction model techniques in testing the time series data. Result showed that lending rates by the banks significantly affect manufacturing output in Nigeria. 
Emenuga, (2019) worked on credit effects of commercial banks on agricultural productivity in Nigeria over a period of 37 years (1981-2017) and adopted ADF unit root test, Johansen cointegration test and error correction model techniques where employed as analytical tools. The study revealed that agricultural credit and Agricultural credit guarantee scheme are positively related to Agricultural development while interest rate showed negative relationship with agriculture. The work suggested for the elimination of delay and stringent conditions in assessing commercial bank credit facilities.

A work on agricultural credit and economic growth nexus was conducted by Ayeomoni \& Aladejana, (2016). Adopting Auto-Regressive Distributed Lag (ARDL) approach to analyze CBN time series data which spanned from 1986-2014. The work revealed greater impact of credit for agriculture on growth of the economy.

A study carried out by Okosodo, (2016) on agricultural credit and the growth of the "Nigerian Economy used Co-integration and error correction mechanism techniques were employed in testing the time series data. The paper found economic growth and agriculture on a long existing moderate relationship due to expenditure of the government.

"Small and Medium Scale Enterprises was studied by Oluseyi, et al, (2013). The use of inferential and descriptive statistics such as simple percentages, rating indices, and the Students t-distribution was adopted in the data analysis. It was found that that SME did not quite measure up to public expectation on a major performance index of linking small and medium enterprises (including cooperative societies) with cheaper sources of finance.

Zwingina, et al. (2018) in their study of "Formal and Informal Financing sources and Women Entrepreneurship Development in Abuja, utilizing simple percentages, charts, correlation and regression to analyzed the data. The study discovered a positive significance relationship between formal source of financing and women entrepreneurship development and a positive significance relationship between informal sources of financing and Women entrepreneurship development in Abuja, FCT. It was suggested that government collaboration with stakeholders in policy decisions, ensure that funds are available to women entrepreneurship through corporative societies, microfinance banks, commercial banks and bank of industry were suggested.

Reviewed studies have shown that both manufacturing and agricultural sectors have been assumed to play passive and supportive roles in economic growth and development. Their primary purpose is to provide employment, manufactured goods, income and sufficient lowpriced food. And to a large extent, apart from playing an indispensible part in any overall strategy of sustaining the flow of foreign exchange, they have come to be regarded in finance as essential condition for economic growth and development through inter-sectoral linkages such as raw material supplies, food, foreign exchange earnings and others (Nwanyanwu, et al., 2016).

\section{Methodology}

According to Nelson, Ekokeme, Okoyan and Dumani (2018), ex-post facto study design refers to descriptive study in that a predictor variable has existed and in that a fact finder starts with an observation of the outcome variable then studies the predictor variable in retrospect for possible 
relationship and impact on the outcome variable. This study adopted ex-post facto study design and was conducted in Nigeria. This study basically covers the analysis of banks' lending to small and medium enterprises in the agricultural and manufacturing sectors in Nigeria. The population comprise all SME in the agricultural and manufacturing firms in Nigeria obtained from the Small and Medium Scale Enterprises Development Agency of Nigeria (SMEDAN) annual Bulletin and Statistics (various issues). Data were sourced from CBN and SMEDAN Annual statistical bulletin of various years 1981-2018.

Operational variables for this study are bank credits to the manufacturing and agricultural sectors while the dependent variable is the total number of registered entrepreneurs in the agricultural and manufacturing sectors of the Nigerian economy as proxy for entrepreneurship development. This variable is expected to embody the net outcome of bank loans as it affects the small and medium enterprises comprising agriculture and the manufacturing sectors.

\section{Model Specifications}

This work shall employ the multiple regression models to analyze relationship between the dependent variable and independent variables. Performance of the SME is seen to be a function of the level of banks' lending to both agricultural and the manufacturing sectors. This is an extension of the model of (Taiwo \& Omosomi, 2018) which is modified to suit our purpose. Consequently, Entrepreneurship development is proxied by the number of registered SMEs in both sectors (agricultural and manufacturing sectors) and is functionally represented as:

ENT_DEV $=\mathrm{f}(\mathrm{BLAS}, \mathrm{BLMS})$

Overall, utilizing regression model, the linear expression of the model in (3.1) above is expressed as;

ENT_DEV ${ }_{\mathrm{t}}=\beta_{0}+\beta_{1} \mathrm{BLAS}_{\mathrm{t}}+\beta_{2} \mathrm{BLMS}_{\mathrm{t}}+\mathrm{e}_{\mathrm{t}} \ldots \ldots \ldots \ldots \ldots \ldots(3.2)$

Where;

ENT_DEV = Entrepreneurship Development (represented by the subsisting number of registered SMEs or entrepreneurs in agricultural and manufacturing sectors)

BLAS = Banks' Lending to the Agricultural Sector

BLMS = Banks' Lending to the Manufacturing Sector

$\mathrm{e} \quad=$ Error Term of the Regression Model

$\beta_{0} \quad=$ Slope or Intercept of the Regression Model

$\beta_{1}, \beta_{2} . \quad=$ Unknown Coefficients of the model to be estimated

\section{Techniques of Data Analysis}

The Autoregressive Distributive Lag (ARDL) model which is an extension of the Ordinary least square (OLS) is the most appropriate technique for estimation of the model parameters. The preference of the ARDL model is motivated by its appealing statistical and econometric properties as well as the fact that pre-estimation tests (Unit root and Bounds test) suggests the use of the ARDL model. Pesaran and Shin (2001) posited that the estimation of a model that have mixed orders of integration is best explained using the Autoregressive Distributive Lag 
(ARDL) model which gives both the short run and long run coefficients of the model. The ARDL model also explains the total variations in the dependent variable caused by variation in the explanatory variables computed in the model.

\section{A- Priori Expectation}

A priori expectation is an assumed likelihood of the outcome of analysis thus stated as;

$$
\beta_{0}>0 ; \beta_{1}>0 ; \beta_{2}>0 .
$$

\section{Analysis of Data}

The analysis is preceded by the test for unit root or stationarity of the variables. This is summarized below:

\section{ADF Unit Root Test}

Table 4.1: Augmented Dickey Fuller (ADF) Unit Root Test

\begin{tabular}{lll|ll} 
& ADF test statistics & Order of & Decision \\
\cline { 2 - 5 } Variables & At Level & At First Difference & Integration & \\
\hline ENT_DEV & 1.211968 & 4.739710 & $\mathrm{I}(1)$ & Stationary at $1^{\text {st }}$ difference \\
BLAS & 4.700569 & -2.863629 & $\mathrm{I}(0)$ & Stationary at Level \\
BLMS & 0.092882 & 3.848779 & $\mathrm{I}(1)$ & Stationary at $1^{\text {st }}$ difference \\
5\% critical value $=-2.976263$ & &
\end{tabular}

The stationarity test above shows that entrepreneurship development and bank lending to the manufacturing sector are both integrated of order one I(1) i.e. they are stationary at first difference. Data on bank lending to the agric sector is integrated of order zero I(0) i.e. it is stationary at level. This implies that the variables have mixed order of integration thus necessitating the Autoregressive Distributed Lag model (ARDL) approach to cointegration (Pesaran and Shin, 2001) as shown below.

\section{Bounds Test for Co-integration}

Table 4.2: ARDL Bounds Test for Co-integration

Null Hypothesis: No long-run relationships exist

\begin{tabular}{lcc}
\hline \hline Test Statistic & Value & $\mathrm{k}$ \\
\hline \hline F-statistic & 25.46898 & 2 \\
\hline \hline Critical Value Bounds & \\
\hline \hline Significance & I0 Bound & I1 Bound \\
\hline \hline $10 \%$ & 3.17 & 4.14 \\
$5 \%$ & 3.79 & 4.85 \\
$2.5 \%$ & 4.41 & 5.52 \\
$1 \%$ & 5.15 & 6.36 \\
\hline \hline
\end{tabular}


A cursory look at the Bounds test summarized in table 4.3 above shows that the F-statistic value of 25.47 is greater than the $\mathrm{I}(0)$ and $\mathrm{I}(1)$ critical value bounds at $5 \%$ (3.79 and 4.85 ). Thus, we reject the null hypothesis and conclude that a long run relationship exists between bank lending and entrepreneurial development in the agric and manufacturing sectors in Nigeria.

Consequently, we estimate the short run and long run parameters of the model using the Autoregressive Distributive Lag (ARDL) model technique.

Short Run Estimates of the ARDL Model

Table 4.4: Summary of the Short Run ARDL Model

\begin{tabular}{crrrr}
\hline \hline Variable & Coefficient & Std. Error & t-Statistic & Prob.* \\
\hline \hline ENT_DEV(-1) & 0.560832 & 0.135174 & 4.148948 & 0.0004 \\
ENT_DEV(-2) & 0.354838 & 0.221409 & 1.602636 & 0.1221 \\
BLAS & -475.0891 & 106.9097 & -4.443834 & 0.0002 \\
BLAS(-1) & -135.3042 & 91.98623 & -1.470918 & 0.1543 \\
BLAS(-2) & 100.0923 & 107.2656 & 0.933126 & 0.3600 \\
BLAS(-3) & 523.2941 & 101.8300 & 5.138898 & 0.0000 \\
BLMS & 49.65634 & 33.24972 & 1.493436 & 0.1484 \\
BLMS(-1) & -39.12865 & 37.00204 & -1.057473 & 0.3008 \\
BLMS(-2) & -111.8189 & 34.03963 & -3.284961 & 0.0031 \\
BLMS(-3) & 230.2933 & 41.37396 & 5.566142 & 0.0000 \\
CointEq(-1) & -0.084331 & 0.012112 & -6.962599 & 0.0044 \\
C & 8427.317 & 5035.203 & 1.673680 & 0.1072 \\
\hline \hline R-squared & 0.962355 & Mean dependent var & 130462.6 \\
Adjusted R-squared & 0.919170 & S.D. dependent var & 132532.9 \\
F-statistic & 31.15503 & Akaike info criterion & 22.15287 \\
Prob(F-statistic) & 0.000000 & Durbin-Watson stat & 1.685670 \\
\hline \hline
\end{tabular}

The lag of the ARDL model was automatically computed and selected using the Akaike information criterion (AIC). The lag structure of ARDL $(2,3,3)$ was selected after a review of top 20 models based on the least possible AIC values (see Appendix). This implies that the maximum number of years prior to the current year being estimated is 2 years for the dependent variable, and 3 years each for the two independent variables (BLAS and BLMS).

The short run estimates of the ARDL model is summarized in Table 4.4 above. The relationship between bank lending and entrepreneurship development in the agric and manufacturing sectors is explained below as follows:

Bank Lending to the Agricultural Sector (BLAS): The second and third period lag coefficients of this variable are positive increasing by 100.09 and 523.29 units respectively. In other words, bank lending to the agric sector increased entrepreneurial development in the previous years. However, the current year and the first period lag have negative coefficients meaning that they have decreasing effect on entrepreneurship development in the current period. 
This is a pointer to the fact that bank lending to the agric sector has been on the decrease with the current year having a significant negative effect on entrepreneurship development.

Bank Lending to the Manufacturing Sector (BLMS): The current year coefficient is positive but not significant increasing entrepreneurship development by 49.66 units. The first and second period lags are negative while the third period lag is negative. This shows a sort of fluctuation in bank lending to the manufacturing sector and its effect on entrepreneurship development.

Error Correction Coefficient (ECM-1): There is long run convergence in the model since the coefficient of the error correction is negative and significant. Thus, at an estimated speed of $8.4 \%$ annually, the model or system returns to long run equilibrium, all things being equal.

\section{Long Run Estimates of the ARDL Model}

Table 4.5: Long Run Coefficients

\begin{tabular}{crrrr}
\hline \hline Variable & Coefficient & Std. Error & t-Statistic & Prob. \\
\hline \hline BLAS & 154.074125 & 14.122763 & 0.109096 & 0.9140 \\
BLMS & 15.297191 & 2.409580 & 6.348489 & 0.0315 \\
C & 9.993187 & 13.883057 & 0.719812 & 0.4786 \\
\hline \hline
\end{tabular}

The long run relationship is explained below:

Bank Lending to the Agricultural Sector (BLAS): This has a positive long run coefficient of 154.074 which implies that a unit increase in bank lending to the agric sector will result to 154.074 units increase in entrepreneurship development. This shows that bank lending to the agric sector has increased SMEs in the sector which spurs growth in the economy. However, the positive effect of bank lending to the agric sector is not being felt significantly due to the insignificant p-value of 0.9140 .

Bank Lending to the Manufacturing Sector (BLMS): The positive coefficient of 15.297 implies that there is a direct relationship between bank lending to the manufacturing sector and entrepreneurship development in Nigeria. The manufacturing sector has had its own fair share of bank lending leading to the significant effect of lending to this sector on entrepreneurship development. The significant $p$-value of 0.0315 points to the fact that there is a bright future for entrepreneurship development, especially in the manufacturing sector, given a sustained influx of bank lending to the sector.

Intercept: The intercept of the model is estimated at 9.993 units. This entails that holding bank lending variables constant at zero, entrepreneurship development will continue to increase by 9.993 units per annum. This shows that there are other intervening variables that aid the development of entrepreneurs in the agric and manufacturing sectors, which are not captured in our model but are adequately taken care of by the stochastic error term " $e$ ". 
Journal DOI: 10.46654/ij.24889849

Vol. 6, Issue 2 (February, 2020) | www.ijaar.org

Article DOI: 10.46654/ij.24889849.s6253

Test of Hypotheses

Table 4.6: Summary of T-test

\begin{tabular}{llll}
\hline Variables & t-statistic & $\boldsymbol{p}$-value & Decision Rule \\
\hline BLAS & 0.109096 & 0.9140 & Not statistically significant \\
BLMS & 6.348489 & 0.0315 & Statistically significant \\
\hline
\end{tabular}

Source: Extracted from Eviews Output (See Appendix)

\section{Hypothesis One}

$\mathrm{Ho}_{1}$ : There is no significant relationship between bank loans to the agricultural sector and entrepreneurship development in the agricultural and manufacturing sectors of the Nigerian economy.

$$
\begin{aligned}
& \text { t-statistic }=0.1091 \\
& p \text {-value }=0.9140
\end{aligned}
$$

Decision Rule: Since the probability value of the $t$-statistic is greater than the 0.05 critical value, we accept the null hypothesis and conclude that there is no significant relationship between bank loans to the agricultural sector and entrepreneurship development in the agricultural and manufacturing sectors of the Nigerian economy.

\section{Hypothesis Two}

$\mathrm{Ho}_{2}$ : There is no significant relationship between bank loans to the manufacturing sector and entrepreneurship development in the agricultural and manufacturing sectors of the Nigerian economy.

$$
\begin{aligned}
& \mathrm{t} \text {-statistic }=6.3485 \\
& p \text {-value }=0.0315
\end{aligned}
$$

Decision Rule: The probability value of the t-statistic $(0.0315)$ is less than the 0.05 critical value; therefore, we reject the null hypothesis and conclude that there is significant relationship between bank loans to the manufacturing sector and entrepreneurship development in the agricultural and manufacturing sectors of the Nigerian economy.

\section{Diagnostic Tests}

The value of the Durbin Watson statistic is estimated at 1.6857 which implies that there is no autocorrelation in the model. In other words, the error terms do not serially correlate. Furthermore, the adjusted R-square shows that about $92 \%$ of the total variations in entrepreneurship development are accounted for by bank lending to the agric and manufacturing sectors. The F-statistic shows joint influence of bank lending to the real sector on entrepreneurship development with F-statistic of 31.155 and a highly significant p-value of 0.0000 .

\section{Discussion of Findings}

The findings made in this study are very relevant in the study of bank lending and entrepreneurship development in Nigeria, especially now that diversification of the economy is one of the key points of the medium term economic growth plan. The study used total number of registered entrepreneurs in the agric and manufacturing sectors as proxy for entrepreneurship 
development, while bank lending to the agricultural and manufacturing sectors were the explanatory variables of the model. Preliminary tests of stationarity and cointegration showed that the variables have mixed order of integration with entrepreneurship development and bank lending to the manufacturing sector attaining stationarity after first differencing while bank lending to the agricultural sector became stationary at level. This necessitated the Bounds test approach to cointegration since the variables have mixed orders of integration, and the Bounds test confirmed the existence of a long run relationship amongst the variables.

Consequently, the ARDL model was estimated by first estimating the short run coefficients. The result showed that previous values of bank lending to the agric and manufacturing sectors had positive effects on entrepreneurship development while current relationship between the variables showed negative effect of bank lending to both sectors on the development of entrepreneurs in the sectors. Again, bank lending to the manufacturing sector was positively related to entrepreneurship development in the current year but was negative in the previous two years i.e. first and second period lags. This shows that the manufacturing sector have received more of bank lending in the short period which has not also related to a significant leap in entrepreneurial activities in the real sector. The agric sector has not benefitted optimally from bank lending owing to the stringent conditions to be met before as well as the high rates of interest and diversion of funds meant for the real farmers to other uses. This is consistent with the work of Foluso et al. (2019) which revealed positive significant relationship between deposit money bank loans to small and medium enterprises, gross fixed capital formation and growth of the manufacturing sector in Nigeria.

Furthermore, the ARDL long run model was estimated and the result showed positive effects of bank lending to the agric and manufacturing sectors on entrepreneurship development. However, in terms of individual significance, only bank lending to the manufacturing sector significantly impacted on entrepreneurship development for the period reviewed while agric sector loans did not significantly impact on SMEs development in the real sector. This result agrees with the findings of Emenuga (2019) which revealed that commercial banks' credit to Agriculture and Agricultural credit guarantee scheme are positively related to Agricultural development in Nigeria. The model showed no autocorrelation problem while the bank lending variables had joint effect on the dependent variable contributing about $92 \%$ jointly to entrepreneurship development in the agriculture and manufacturing sectors.

\section{Conclusion}

The financial intermediation role of the banking sector is the single most important function of the sector to the productive sectors of the economy. Banks lend to the real sector which is the productive sector and this helps to facilitate and enhance production. This study looked at bank lending and its effect on entrepreneurship development in the agric and manufacturing sectors. The study argued that increase in the number of registered entrepreneurs in the agric and manufacturing sectors (real sector) is a function of increased bank lending to the sectors. Thus, with the availability of more loans at low rates of interest, entrepreneurs will be motivated to carry out their businesses thus enhancing production and sustaining the economy. After a thorough analysis, the study found that bank lending to the agric sector has not really lived up to expectation as the variable had insignificant effect on entrepreneurship development. The 
manufacturing sector was better off with positive and significant coefficients in the model which accounted for up to $92 \%$ of the variations in entrepreneurship development. Thus, the study concludes that bank lending has favored the manufacturing sector rather than the agricultural sector. Also, there is short run negative effect of bank loans to the agric sector on entrepreneurship development while the long run effect is not felt significantly. There is need to prevail on the banks to increase their lending activities especially to the agric sector and ensure prudent use of these funds by adopting one or a combination of the recommendations made below.

\section{Recommendations}

The study recommends as follows: Banks should as a matter of urgency increase their loans to the agricultural sector by providing incentives that will attract farmers. Incentives such as lower interest rates, fertilizer subsidization and free extension services should be considered. Banks should put all machinery in place to ensure that loans to the agricultural sector are used for the purpose for which they were meant. This will help to increase the rate of repayment of the loans and increase the loan worthiness of most farmers. The manufacturing sector should not be left out in the scheme of banks' lendings as they have shown to benefit more from these loans and have also increased in terms of more entrepreneurs springing up over the years. There should be a national data base of registered farmers and their loans history so as to facilitate loans to the agricultural sector. 


\section{References}

Ayeomoni, O. \& Aladejana, S. A., (2016): "Agricultural Credit and Economic Growth Nexus. Evidence from Nigeria." International Journal of Academic Research in Accounting, Finance and Management Sciences. 6(2), 146 - 158.

Aremu, M.A. \& Adeyemi, S.L. (2011) "Small and Medium Scale Enterprises as a Survival Strategy for Employment Generation in Nigeria". Journal of Sustainable Development. 4(1), 198 - 2017.

Adeleke, G. S. \& Elumah, L. O., (2018): “Deposit Money Banka and Entrepreneurship Development in Nigeria. Journal of Research and Opinion. 5(9), 2231-2238.

Emenuga, P. (2019). "Equity Financing and Bank Performance in Nigeria: Special Performance in First Bank in Nigeria.” Journal of Humanities and Social Sciences. 24(4),17 - 23.

Foluso, O. A., Abdul-Lateef, O. A, Rotimi, O., Adesina, S. Y. \& Ridwan, B. O., (2019): “The Role of Deposit Money Banks' Loan Facilities in Financing Small and Medium-Scale Enterprises in Nigeria. Academic Journal of Interdisciplinary Studies. 8(2). 277 - 284. Doi: 10.2478/ajis-2019-0040.

Hussain, M.D., Bhuiyan, A.B. \& Bakar, R. (2014).Entrepreneurship development and poverty alleviation: An empirical review. Journal of Asian Scientific Research, 4(10), 558-573.

Ikpor, R., Nnabu, B. E \& Obaji, S. I. (2017). Bank lending to small and medium scale enterprises and its implication on economic growth in Nigeria. IOSR Journal of Humanities and Social Sciences, 22(12), 14-28

Journal of Academic Research in Business and Social Sciences, 8(3), 57 - 69.

Kalu, E. U., Obasikene, A. C., Oleka, C. D., Nwadike, A. O. \& Okoyeuzu, C. (2017): “The Relative Impact of Bank Credit on Manufacturing Sector in Nigeria". International Journal of Economics and Financial Issues. 7(2). 196 - 201.

Muogbo, U. S. \& Tomola, O. (2018): "The Impact of Microfinance Bank on Entrepreneurship Development in Nigeria. Journal of Business and Economic Development. 3(2). 51 - 61. doi: $10.11648 /$ j.jbed.20180302.13

Nwanyanwu, D. H., Amadi, C. R., Kelvin N. \& Turakpe, M. J., (2016): "Spatial Analysis of Fadama III Rural Infrastructure and Agricultural Performance in Omuma Local Government Area of Rivers State, Nigeria. African Social \& Educational Journal. 5(2); $164-173$.

Nwankwo, O. C. (2006): A Practical Guide to Research Writing. Revised Second Edition. Pan Unique Publishers, Port Harcourt. p. 23

Nelson, J. \& Ayawei, M. J., (2018): “Deposit Money Loans to SMEs and its Effect on Economic Growth in Nigeria (1992 - 2016). International Journal of Economics, Business and 
Management Research. 2(3). $434-467$.

Ogunsakin, S. (2014): "Nigerian Financial Sector and Manufacturing Industries. Journal of Applied Chemistry. 7(3), 41-46.

Oduntan, K.O. (2014) the role of Small and Medium Enterprises in Economic Development: The Nigeria experience. International Conference on Arts, Economics and Management (ICAEM’ 14) March 22-23, Dubai.

Okosodo, L. A. (2016): "Agricultural Credit on the Growth of the Nigerian Economy. International of Education and Research. 4(12), 265 - 276.

Ogunsakin, S. (2014): "Nigerian Financial Sector and Manufacturing Industries. Journal of Applied Chemistry. 7(3), 41-46.

Oluseyi, O. O., Solomon A. A., \& Adekunle O. B., (2013): "Financing Small Business in Ogun State, Nigeria: The Critical Role of the Small and Medium Enterprises Development Agency of Nigeria (SMEDAN). International Journal of Academic Research.1 (1), $32-43$.

Sanusi, L. S. (2011): Banks in Nigeria and National Economic Development: A Critical Review. Keynote Address at the Seminar on "Becoming an Economic Driver while applying Banking Regulations", organized by the Canadian High Commission in Collaboration with the Chartered Institute of Bankers of Nigeria and Royal Bank of Canada, on March, $7,2011$.

Okosodo, L. A. (2016): "Agricultural Credit on the Growth of the Nigerian Economy. International of Education and Research. 4(12), 265 - 276.

Schumpeter, J. (1934). The theory of economic development. Cambridge, MA: Harvard University Press.

Sushmitha, R. S. \& Swathi, B. A, (2018): "The Role of Banks in the development of entrepreneurship in India.' Journal of Business and Management. 20(7), 71 - 74.

Tomola, M. O., Adekunle, A., Adebisi, T. E. \& Olawale, F. K. (2018):” Bank Lending, Economic Growth and the Performance of the Manufacturing Sector in Nigeria. European ScientificJournal. 8(3). 16-36.

Taiwo, O. \& Omosomi, O. (2018): "Evaluating Agriculture Finance in Nigeria: Towards the US\$1 trillion African food market by 2030. Available: https://www.pwc.com/ng/en/assets/pdf/evaluating-agric-finance-nigeria.pdf

Zwingina, T. C., Opusunju, M. I. \& Nuhu, D. G., (2018): "Formal and Informal Sources of Financing and Women Entrepreneurship Development in Abuja. Social Sciences Journal of Policy Review and Development Strategies. 5(1). $43-5$ 